\title{
Spectroscopic detection of a ubiquitous dissolved pigment degradation product in subsurface waters of the global ocean
}

\author{
R. Röttgers ${ }^{1}$ and B. P. Koch ${ }^{2,3}$ \\ ${ }^{1}$ Helmholtz-Zentrum Geesthacht, Center for Materials and Coastal Research, Institute for Coastal Research, Max Planck \\ Str. 1, 21502 Geesthacht, Germany \\ ${ }^{2}$ Alfred Wegener Institute for Polar and Marine Research, Am Handelshafen 12, 27570 Bremerhaven, Germany \\ ${ }^{3}$ University of Applied Sciences, An der Karlstadt 8, 27568 Bremerhaven, Germany
}

Correspondence to: R. Röttgers (rroettgers@hzg.de)

Received: 12 October 2011 - Published in Biogeosciences Discuss.: 31 October 2011

Revised: 4 June 2012 - Accepted: 4 June 2012 - Published: 13 July 2012

\begin{abstract}
Measurements of light absorption by chromophoric dissolved organic matter (CDOM) from subsurface waters of the tropical Atlantic and Pacific Oceans showed a distinct absorption shoulder at $410-415 \mathrm{~nm}$. This indicates an underlying absorption of a pigment whose occurrence is partly correlated with the apparent oxygen utilization (AOU) but also found in the deep chlorophyll maximum. A similar absorption maximum at $\sim 415 \mathrm{~nm}$ was also found in the particulate fraction of samples taken below the surface mixing layer and is usually attributed to absorption by respiratory pigments of heterotrophic unicellular organisms. In our study, fluorescence measurements of pre-concentrated dissolved organic matter (DOM) samples from 200-6000 m confirmed a previous study suggesting that the absorption at $\sim 415 \mathrm{~nm}$ was related to fluorescence at $650 \mathrm{~nm}$ in the oxygen minimum zone. The absorption characteristics of this fluorophore was examined by fluorescence emission/excitation analysis and showed a clear excitation maximum at $415 \mathrm{~nm}$ that could be linked to the absorption shoulder in the CDOM spectra. The spectral characteristics of the substance found in the dissolved and particulate fraction did not match with those of chlorophyll $a$ degradation products (as found in a sample from the sea surface) but can be explained by the occurrence of porphyrin pigments from either heterotrophs or autotrophs. Combining the observations of the fluorescence and the 415-nm absorption shoulder suggests that there are high concentrations of a pigment degradation product in subsurface DOM of all major oceans. Most pronouncedly we found this signal in the deep chlorophyll maximum and
\end{abstract}

the oxygen minimum zone of tropical regions. The origin, chemical nature, turnover rate, and fate of this molecule is so far unknown.

\section{Introduction}

Dissolved organic matter (DOM) forms the largest reservoir of reduced organic carbon in the ocean. It consists of a large variety of different compounds (Koch et al., 2005) which represent microbially or photochemically reworked remnants of biomolecules (e.g. McCarthy et al., 1998; Benner, 2002). The overall distribution of DOM in the world's oceans is determined by autochthonous and only partly allochthonous sources, by photodegradation near the sea surface, and by particulate matter remineralization in deeper waters.

Measurement of DOM light absorption is one method used to describe the biogeochemistry and hydrography of different oceanic regions and water masses. The combination of absorption with fluorescence characterization allows for improved insights into the chemical nature and origin of DOM (Stedmon et al., 2003). Chromophoric and fluorescent moieties of the DOM (CDOM and FDOM, respectively) represent only a small part of the DOM pool, but can easily be determined by optical methods. The absorption of CDOM in the aquatic environment has a characteristic spectral shape with a strong absorption in the UV to visible range, which decreases exponentially towards longer wavelengths. The slope of this decrease is used to characterize CDOM sources (e.g. Vodacek et al., 1997) and to describe its molecular 
composition (e.g. Helms et al., 2008). Commonly, samples are taken near the sea surface where dissolved organic carbon (DOC) concentrations are highest and the CDOM absorption can be retrieved by satellite remote sensing. Therefore most scientific studies address CDOM absorption features at the sea surface. Few studies examine the CDOM absorption in deeper waters (e.g. Nelson et al., 2007, 2010; Del Castillo and Coble 2000; Swan et al., 2009). Due to photodegradation at the surface, CDOM absorption is higher below the surface mixing zone. As a substantial proportion of DOM is refractory and resists degradation for several thousand years (Williams and Druffel, 1987; Bauer et al., 1992), CDOM can be used to reconstruct the hydrographic origin of a water mass (e.g. Nelson et al., 2010; Swan et al., 2009).

Due to high concentrations of aromatic structures in DOM, a pronounced shoulder in the CDOM absorption spectrum can usually be found in the UV $(\sim 270 \mathrm{~nm})$ or in the UVA region (Nelson et al., 2011; Steinberg et al., 2004). A previous CDOM absorption study in mesopelagic waters $(600 \mathrm{~m})$ of the Arabian Sea showed an absorption shoulder in the visible wavelengths at around $415 \mathrm{~nm}$ (Breves and Reuter, 2000; Breves, 2001; Breves et al., 2003). The observation of the shoulder was hypothesized to be related to a chlorophyll $a$-like fluorescence observed in the same water depth (Breves, 2001; Breves et al., 2003). A red fluorescence in subsurface waters was reported earlier from the Pacific (Broenkow et al., 1983, 1985, 1992; Lewitus and Broenkow, 1985). In these studies it was concluded that this "deep red fluorescence" is a global feature found in all major oceans and at all latitudes, and that its maximum is associated with the oceanic oxygen minimum zone (OMZ). In addition, it was speculated that chlorophyll $a$ or chlorophyll $a$ degradation products in phytoplanktonic particles are potential molecular precursors. It is, however, still unresolved whether the red fluorescence occurs in the particulate and/or dissolved fraction. Breves et al. (2003) concluded that it is most likely in the dissolved phase based on sample filtration and a fluorescence emission at $\sim 650 \mathrm{~nm}$, which appeared in samples from mesopelagic depth when excited with light of $420 \mathrm{~nm}$. This contradicts earlier results (Broenkow et al., 1992) which often found a close correlation of the "deep red fluorescence" with light attenuation (mainly scattering by particles). Moreover, the exact molecular nature of this phenomenon is still unknown.

An unresolved question is also whether the fluorescence at $650 \mathrm{~nm}$ emits from the chromophore that absorbs at $415 \mathrm{~nm}$. If this is true, the observation of the 415-nm absorption shoulder in the visible spectral range and the "deep red fluorescence" in the subsurface waters are most likely linked. The observed "deep red fluorescence" would then provide evidence that this specific chromophore/fluorophore occurs globally and throughout the water column, and its optical characteristics provide evidence that it is of pigment origin and unique among other chromophoric/fluorescent DOM molecules in the subsurface ocean.

The aims of our study are (i) to demonstrate the occurrence of the 415-nm absorption shoulder in other oceanic regions besides the Arabian Sea; (ii) to clarify whether the absorption at $415 \mathrm{~nm}$ and the fluorescence at $650 \mathrm{~nm}$ originate from the same molecule; (iii) to clarify whether it is found in either the dissolved or the particulate fraction; and (iv) to investigate the distribution of this chromophore/fluorophore in the water column and on a latitudinal transect in the Atlantic Ocean, proofing the hypothesis by Broenkow and coworkers about the global and depth distributions of this "deep red fluorescence". We also tested whether solid-phase extraction is suitable to extract the absorbing CDOM compounds from the sea water matrix and whether the compounds are stable in methanol solution (see e.g. Coble et al., 1990). The concentrated samples are expected to provide better signal to noise ratios for fluorescence analyses.

\section{Materials and methods}

\subsection{Sampling}

Several oceanographic cruises were conducted to collect samples for particulate and CDOM as well as DOM extract absorption measurements. The first cruise (ANT-XXIII/1, R/V Polarstern, Oct/Nov 2005) followed a transect from Germany to Cape Town, South Africa, crossing the Atlantic Ocean along the African continent. During this cruise samples for CDOM and particulate absorption analyses were mainly taken from the surface and at 200-m water depth. At 5 stations in the tropics the entire water column was sampled. One DOM extract was collected from 200-m depth. On the second transect cruise (ANT-XXV/1, R/V Polarstern, November 2008), which covered the same region (Koch and Kattner, 2012), DOM extracts were collected throughout the water column and across the Atlantic (Fig. 1). Additional samples were collected from two other cruises for CDOM and particulate absorption measurements from the surface and from 80-200-m depths: in the West Pacific offshore of New Caledonia (VALHYBIO, R/V L'Alis, Mar/Apr 2008), and in the Santa Barbara Channel (California, Northeast Pacific, RaDyO, R/V Kilo Moana, September 2008).

\subsection{Light absorption measurements}

The light absorption of dissolved (CDOM) and particulate matter, $a_{\text {cdom }}$ and $a_{p}$, respectively, was measured during ANT-XXIII/1 using a point-source integrating cavity absorption meter (PSICAM) as described in Röttgers et al. (2007) and Röttgers and Doerffer (2007). For this, the sample absorption was measured before and after filtration $(0.2 \mu \mathrm{m})$, and the absorption of the filtered fraction was subtracted from the unfiltered sample absorption to obtain particulate absorption. During the $\mathrm{RaDyO}$ cruise the 


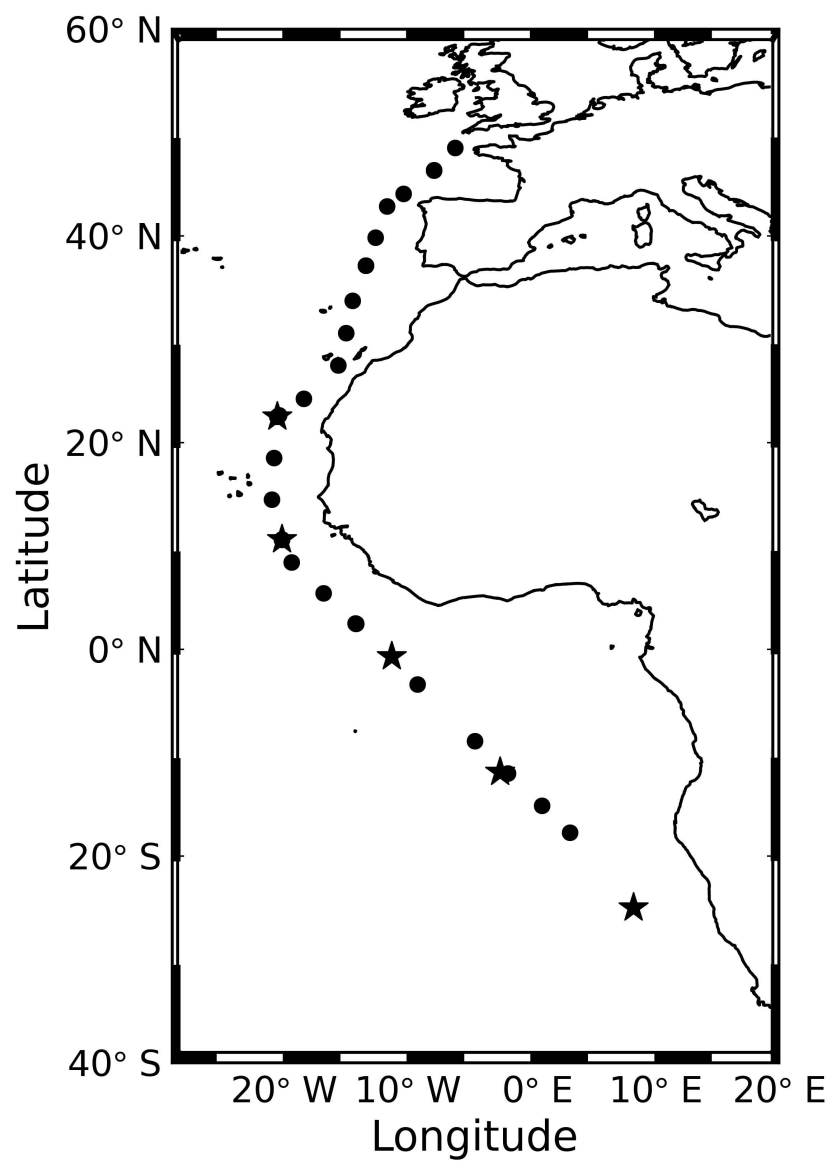

Fig. 1. Geographic positions of relevant sampling stations during the cruises ANT-XXIII/1 (November 2005) and ANT-XXV/1 (November 2008). Shown are the positions of regular sampling stations (solid circles) and those of the five stations at which the whole water column was sampled (stars).

absorption by CDOM was measured additionally using a 2-m path length liquid core waveguide capillary cell (LWCC; Miller et al., 2002). All PSICAM and LWCC measurements were done shortly after sampling $(<2 \mathrm{~h})$ onboard of the ship, using ultrapure water (MilliQ, Gradient, Millipore) as the reference. Measurements were done at least in triplicates and averaged. The absorption coefficient, $a$, was calculated as $a=-\ln T / L\left[\mathrm{~m}^{-1}\right]$, where $T$ is the transmission and $L$ the corrected optical path length of the capillary cell, as provided by the manufacturer (WPI Inc.). Comparison of both CDOM absorption methods revealed insignificant differences, but the LWCC had a wider wavelength range and was preferred when available.

CDOM filtration was done using cleaned glass filtration units. After rinsing with $50-100 \mathrm{~mL}$ of the sample, the first filtration was performed through pre-combusted GF/F filters (Whatman) under low vacuum $(<100 \mathrm{mbar})$ to avoid breakage of phytoplankton cells. The second filtration $(0.2 \mu \mathrm{m}$; washed GWSP filters, Millipore) was carried out applying a vacuum of $200-300$ mbar. Prior to absorption measurements, filtered samples were adjusted to the same temperature as the reference (ultra pure water) to minimize temperature effects. However, slight temperature differences as well as the difference between the salinity of the samples and reference water were individually corrected, using instrument-specific correction coefficients obtained from measurements of concentrated $\mathrm{NaCl}$ solutions. Light absorption $(350-700 \mathrm{~nm}, 2 \mathrm{~nm}$ resolution and slit width) of the methanol DOM extracts were measured in the laboratory against pure methanol as a reference in a Lambda 850 spectrophotometer (Perkin Elmer) using $1-\mathrm{cm}$ path length quartz glass cuvette. The resulting spectra of the ANT-XXV/1 samples were, however, too noisy to resolve the shoulder and perform the following least-square fit.

To determine the absorption of an observed chromophore at ca. $415 \mathrm{~nm}$, the CDOM and particulate absorption spectra of water samples were analyzed with a least-square fit as done by Breves et al. (2003). The absorption was fitted in the range of $370-600 \mathrm{~nm}$ to:

$a(\lambda)=a_{1} e^{-S\left(\lambda-\lambda_{0}\right)}+a_{2} \frac{1}{\sigma \sqrt{2 \pi}} e^{\frac{-\left(\lambda-\lambda_{0}\right)^{2}}{2 \sigma^{2}}}+a_{3}$.

The term on the left side of the equation refers to a typical exponential increase of the CDOM spectrum with decreasing wavelength with the slope $S$ and the absorption $a_{1}\left(\lambda_{0}\right)$. The term in the middle is a Gaussian function used for the additional absorption of a 415-nm chromophore, $a_{c}\left(\lambda_{0}\right)=$ $a_{2} /(\sigma \sqrt{2 \pi})$, where $\sigma$ is the width parameter of the Gaussian function. The last term $a_{3}$ is an absorption parameter to correct for offsets in the absorption at longer wavelength. Applying the exponential fit to our samples, the best fits were obtained for $\lambda_{0}=415$ and $\sigma=25 \mathrm{~nm}$.

\subsection{DOM extraction}

DOM was extracted from 5-L filtered (GF/F, Whatman) seawater samples using solid-phase adsorption (1-g PPL cartridges, Varian) according to Dittmar et al. (2008). Solid-phase extractable DOC (SPE-DOC) accounted for $42 \pm$ $6 \%$ of the total DOC $(n=138)$; and $22 \pm 11 \%$ of the DON was solid-phase extractable $(n=128)$. For details of the extraction method see Flerus et al. (2012).

\subsection{Fluorescence measurements}

Fluorescence emission and excitation spectra from the methanolic DOM extracts were recorded with an AmincoBowman Serie 2 Luminescence Spectrometer in a $1-\mathrm{cm}$ path length quartz glass fluorescence cuvette. Due to the small sample volumes, excitation-emission matrices (EEM) were recorded for selected samples only using different wavelength ranges and signal amplification to amplify low fluorescence features at $>500 \mathrm{~nm}$. EEM measurements were done with a resolution of $2 \mathrm{~nm}$, band widths of $4 \mathrm{~nm}$ for 


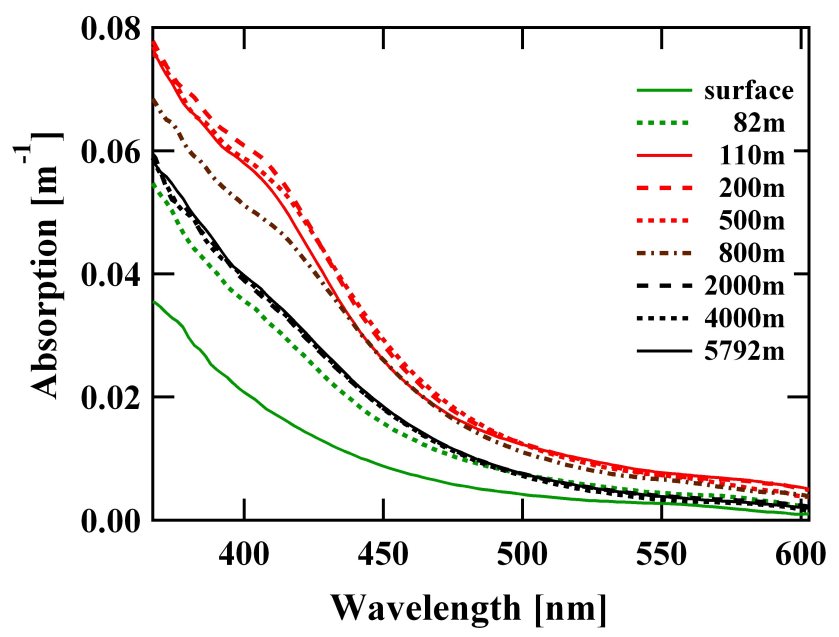

Fig. 2. Light absorption of CDOM in the tropical Atlantic Ocean $\left(12^{\circ} \mathrm{S}, 2^{\circ} \mathrm{W}\right)$ in November 2005 (ANT-XXIII/1) as a function of wavelength, given for water depths between the surface and $6000 \mathrm{~m}$.

excitation (Ex) and emission (Em), and a scan speed of 5-10 $\mathrm{nm} \mathrm{s}^{-1}$ for (i) Ex: $250-500 \mathrm{~nm}, E \mathrm{Em}: 270-500 \mathrm{~nm}$, (ii) Ex: $380-680 \mathrm{~nm}$, Em: $400-700 \mathrm{~nm}$, and (iii) Ex: $380-480 \mathrm{~nm}$, Em: $550-700 \mathrm{~nm}$. The fluorescence signals of these three matrices were normalized to the amplification value (PMT voltage: $550-750 \mathrm{~V}$ ) to adjust for the differences in the signal amplification. For several samples i) single emission spectra $(>370-700 \mathrm{~nm})$ were recorded with an excitation between 250 and $500 \mathrm{~nm}$, and (ii) single excitation spectra $(>350 \mathrm{~nm})$ were recorded for emissions at 490 , 650,670 , and $720 \mathrm{~nm}$. For these single scans the signal to noise level was reduced by applying a slower scan speed $\left(1-2 \mathrm{~nm} \mathrm{~s}^{-1}\right)$, multiple scans $(n=5-10)$ that were averaged, and a band width of $8-16 \mathrm{~nm}$ for the fixed monochromator (i.e. for emission during excitation scans and excitation during emission scans). Internally recorded light intensity of the Ex variation and instrument specific correction factors for Ex and Em were used to correct the raw spectra. In addition, inner filter effects were corrected using absorbance measurement of the sample according to the method by Lakowicz (1999). For all measurements pure methanol was used with the same scan speed, band width, and amplification settings for a subsequent subtraction of Raman and Rayleigh scattering. The spectra were not further calibrated as they were primarily used to show structural but not concentration differences between samples from the surface and subsurface waters. For some spectra, the fluorescence was normalized to the maximum signal or to the measured absorption at $415 \mathrm{~nm}$.

\section{Results}

\subsection{CDOM absorption}

The CDOM absorption spectra from the sea surface measured during ANT-XXIII/1 showed a typical spectral distribution in the UVA to visible (VIS) range (380-700 nm), i.e. an exponential decrease with increasing wavelength without pronounced structures. Along the depth profile CDOM absorption was lowest at the sea surface and typically highest in depth between 100 and $1000 \mathrm{~m}$. Figure 2 shows the CDOM absorption spectra of the sample profile taken in the tropical Atlantic Ocean. Apart from generally higher CDOM absorption in the subsurface water, there was a pronounced absorption shoulder at ca. $415 \mathrm{~nm}$ for intermediate depths $(110-800 \mathrm{~m})$. Even at higher depths this absorption was still observable by a divergence of the exponentially to a more linearly decreasing curve. The "typical" exponential decrease in the CDOM absorption spectra was only found in samples from the sea surface, whereas the shoulder was found in nearly all samples from depths below the surface mixing zone $(40-100 \mathrm{~m})$ as well as in depths of the deep chlorophyll maximum (DCM) just below the mixing layer (e.g. 82 m, Fig. 2).

Five depth profiles in the tropical Atlantic Ocean were examined to test if a chromophore underlies the absorption shoulder at ca. $415 \mathrm{~nm}$. For this, the absorption of the chromophore $\left(a_{\mathrm{c}} 415 \mathrm{~nm}\right)$ and the absorption of the remaining $\operatorname{CDOM}\left(a_{\mathrm{g}} 415 \mathrm{~nm}\right)$ were determined as described above and plotted with the profiles of the potential water density $\left(\sigma^{t}\right)$, apparent oxygen utilization (AOU), and chlorophyll $a$ - like fluorescence (fl_chl; Fig. 3). The values for $a_{\mathrm{c}} 415 \mathrm{~nm}$ were close to zero at the surface and varied from 0.005 to 0.017 $\mathrm{m}^{-1}$ below the surface mixing zone, whereas $a_{\mathrm{g}} 415 \mathrm{~nm}$ varied from 0.1 to $0.2 \mathrm{~m}^{-1}$ and from 0.3 to $0.7 \mathrm{~m}^{-1}$, respectively. In the most pronounced case, $a_{\mathrm{c}} 415 \mathrm{~nm}$ represented $30 \%$ of the CDOM absorption at $415 \mathrm{~nm}\left(a_{\mathrm{c}} 415 \mathrm{~nm}+a_{\mathrm{g}} 415 \mathrm{~nm}\right)$. In all profiles a close correlation between $a_{\mathrm{c}} 415 \mathrm{~nm}$ and the AOU was observed. Linear regression analysis of the data of all profiles shows also a good correlation $\left(r^{2}=\right.$ $0.69, n=44, p<0.001)$. The strong AOU maximum, i.e. the oxygen concentration minimum, ranged from just below $100 \mathrm{~m}$ to about $1000 \mathrm{~m}$ in this region, with a lower extent at $25^{\circ} \mathrm{S}$. However, higher values of $a_{\mathrm{c}} 415 \mathrm{~nm}$ were detected above the AOU maxima, close to the typical deep chlorophyll fluorescence maxima (CFM). Excluding values from the CFM leads to an even better correlation between $a_{\mathrm{c}} 415 \mathrm{~nm}$ and AOU $\left(r^{2}=0.89, n=33, p<0.001\right)$. CDOM absorption, $a_{\mathrm{g}} 415 \mathrm{~nm}$, is less strongly correlated with AOU $\left(r^{2}=0.27, n=44, p<0.001\right)$ and in two cases $\left(23^{\circ} \mathrm{N}\right.$ and $11^{\circ} \mathrm{N}$ ) showed highest values in the CFM, not in the AOU maximum. Regular water sampling at $200-\mathrm{m}$ water depth showed a higher CDOM absorption at $415 \mathrm{~nm}$ in the tropics between $20^{\circ} \mathrm{N}$ and $15^{\circ} \mathrm{S}$ (Fig. 4, upper panel). The depth profiles in Fig. 3 show that the values of $a_{\mathrm{c}} 415 \mathrm{~nm}$ at 


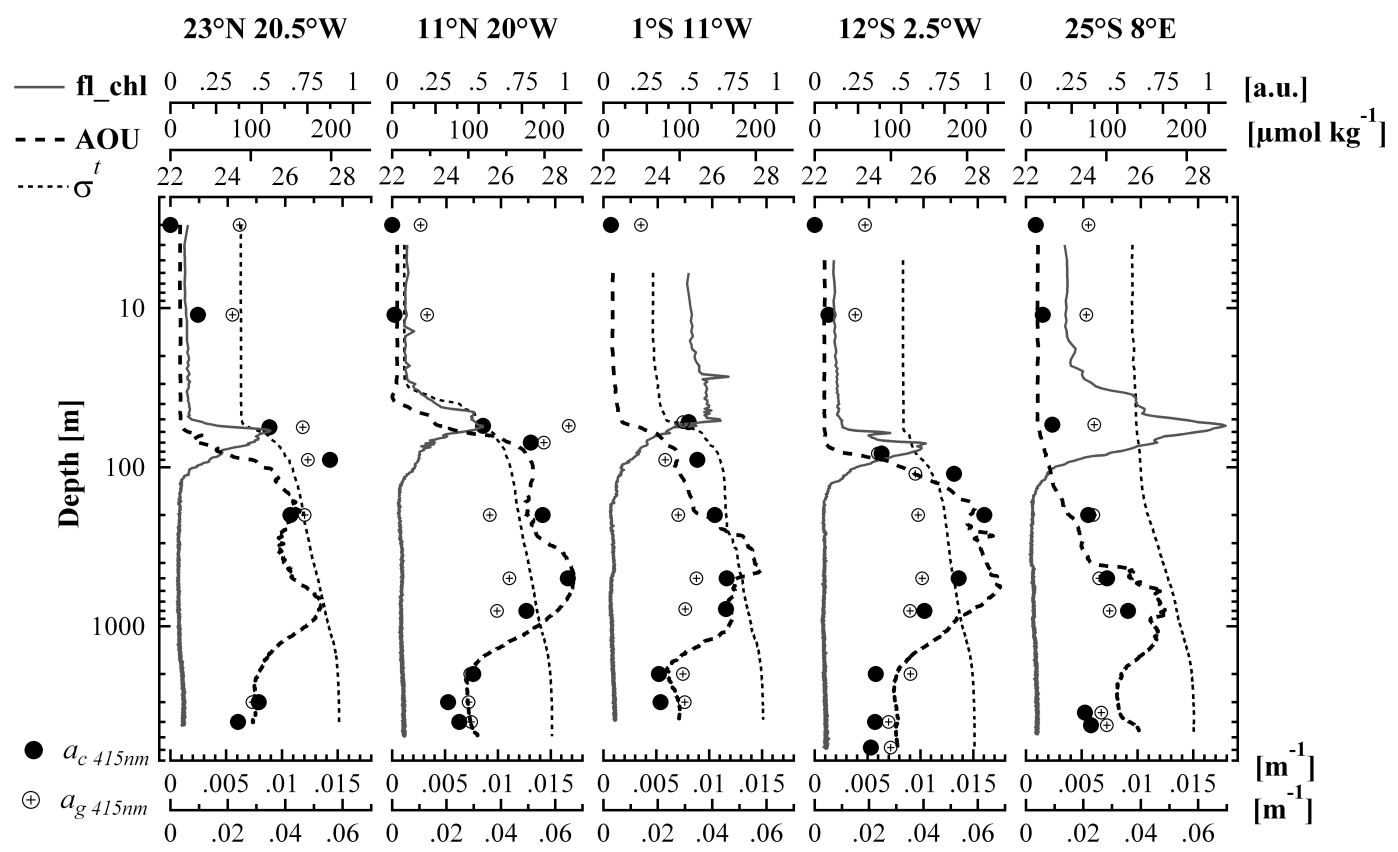

Fig. 3. Depth profiles of seawater density anomaly, $\sigma^{t}$; apparent oxygen utilization, AOU; chlorophyll $a$-like fluorescence, fl_chl; the

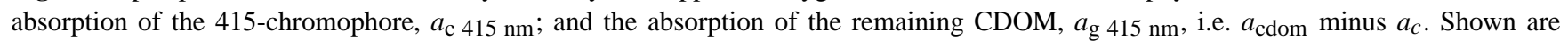
five profiles taken between $23^{\circ} \mathrm{N}$ and $25^{\circ} \mathrm{S}$ in the eastern Atlantic Ocean in November 2005 (ANT-XXIII/1).

$200 \mathrm{~m}$ are close to the maximum values found in the oxygen minimum between ca. $25^{\circ} \mathrm{N}$ and $13^{\circ} \mathrm{S}$, and are hence a good representative of $a_{\mathrm{c}} 415 \mathrm{~nm}$ in the whole water column. The absorption of the chromophore, $a_{\mathrm{c}} 415 \mathrm{~nm}$, varied during the latitudinal transect between 0.0046 and $0.0175 \mathrm{~m}^{-1}$ (Fig. 4, lower panel), with the highest values in the tropics.

Additional samples from water depths of up to $200 \mathrm{~m}$ taken from the shallow Santa Barbara Channel (SBC, Californian coast, Northeast Pacific, bottom depth ca. $200 \mathrm{~m}$ ) and offshore of New Caledonia (West Pacific, bottom depth $>2000 \mathrm{~m}$ ) were included in this study. In both regions an absorption shoulder at $415 \mathrm{~nm}$ was found in the depths below the mixed surface layer (Fig. 5), whereas the surface samples showed typical surface CDOM spectra without a visible shoulder (data not shown).

\subsection{Particulate absorption}

The particulate absorption was determined for each sample to check whether the CDOM absorption was derived from the particulate fraction $(>0.2 \mu \mathrm{m})$. At the surface the particulate absorption in the ocean is usually dominated by phytoplankton pigment absorption, whereas in the deep sea it is dominated by heterotrophs (mainly bacteria) and non-living matter. Surface samples and samples from the DCM were ignored as the phytoplankton pigment maxima and shoulders mask the distinct shoulder at $415 \mathrm{~nm}$. On the other hand, particulate absorption in the deep sea is very low and, thus, difficult to measure. The PSICAM provides a sensitive method to determine particulate absorption; nevertheless, the absorption was often below the detection limit. Therefore, measurements could only be carried out for the samples from the SBC and a few samples from the Atlantic Ocean (Fig. 6). The spectra showed an absorption maximum at $415 \mathrm{~nm}$ in all samples from $90-200 \mathrm{~m}$ and no pronounced maxima in samples taken from depth $>2000 \mathrm{~m}$ in the Atlantic Ocean. The absorption spectra from these deep water samples showed a typical detritus absorption, i.e. an exponential decrease with increasing wavelength with a slope lower than the slope for CDOM absorption. The particulate absorption at $415 \mathrm{~nm}$ was lower than the respective CDOM absorption due to the high concentration of DOM compared to particulate organic matter (POM). The particulate absorption of the $415-\mathrm{nm}$ chromophore, $a_{\mathrm{c}} 415 \mathrm{~nm}$, of the Atlantic Ocean samples from the depth of $200 \mathrm{~m}$ was determined by a least-square fit and ranged between 0.0029 and $0.0044 \mathrm{~m}^{-1}$.

\subsection{DOM fluorescence and absorption: original water and methanol extracts}

In November 2005 (during ANT-XXIII/1) only a single DOM extract was collected from a $200-\mathrm{m}$ sample to verify the occurrence of the shoulder in concentrated DOM samples and to further analyze a possible fluorescence associated with the 415-nm absorption shoulder. This DOM methanolic extract showed the same absorption shoulder at $415 \mathrm{~nm}$ as the original water sample (Fig. 7), proving that DOM 


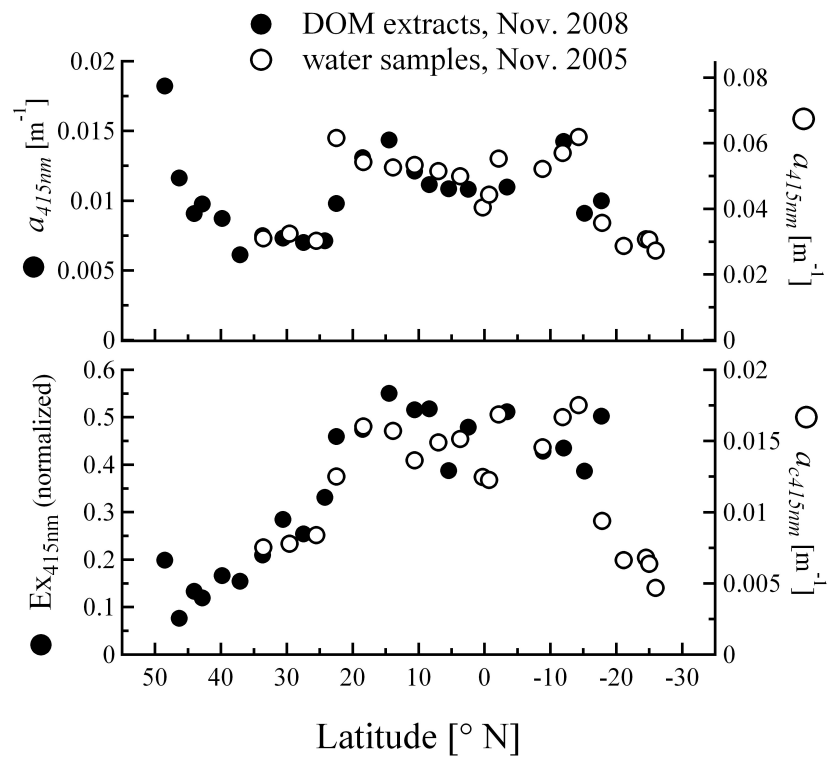

Fig. 4. Latitudinal distribution of the CDOM absorption at $415 \mathrm{~nm}$ in the eastern Atlantic Ocean, $a_{415} \mathrm{~nm}$ (upper panel); and 415-nm chromophore absorption, $a_{\mathrm{c}} 415 \mathrm{~nm}$, and normalized fluorescence excitation, $E x_{415} \mathrm{~nm}$ (both lower panel). Measurements of $a_{415} \mathrm{~nm}$ and $a_{\mathrm{c}} 415 \mathrm{~nm}$ were done in November 2005 during ANT-XXIII/1 directly on water samples (open symbols) and those for $a_{415} \mathrm{~nm}$ and $E x_{415} \mathrm{~nm}$ in November 2008 during ANT-XXV/1 on DOM extracts (closed symbols). Note the differences in axis scale of the upper panel, probably due to incomplete sampling and extraction the absolute absorption determined from the extract is lower by a factor of four.

extraction was a good method to concentrate DOM for a later lab analysis. Then, in November 2008 (during ANT-XXV/1), a set of DOM extracts from the surface and several depths down to the sea bottom were collected. Figure 8 shows the composite of three matrices of one sample from the sea surface and one from $200 \mathrm{~m}$. There is a strong maximum at $330 \mathrm{~nm} / 420 \mathrm{~nm}(\mathrm{Ex} / \mathrm{Em})$ in both samples and some smaller peaks in the UV and short-VIS. The surface sample showed a low but distinct maximum at $410 \mathrm{~nm} / 670 \mathrm{~nm}$, whereas a similar maximum in the $200 \mathrm{~m}$ sample occurred at $415 \mathrm{~nm} / 650 \mathrm{~nm}$. The relevant emission spectra are shown in Fig. 10a. The spectral absorption related to these emissions were examined by single excitation spectra (Ex: 370-630/-650/-690 nm, Em: 650/670/720 nm, respectively). The emission wavelength of $720 \mathrm{~nm}$ was used to examine absorption features around the emission maxima for each sample. Figure 10b shows the excitation spectra for these two samples (surface and $200 \mathrm{~m}$ ). The surface sample showed a strong excitation maximum at $415 \mathrm{~nm}$ and smaller, and rather narrow maxima at ca. 509, 538, 608 and $665 \mathrm{~nm}$. The sample from 200-m depth had a distinct maximum at $415 \mathrm{~nm}$ and smaller, broad maxima at ca. 512 and $552 \mathrm{~nm}$, and no clear features at $>600 \mathrm{~nm}$. The excitation maximum

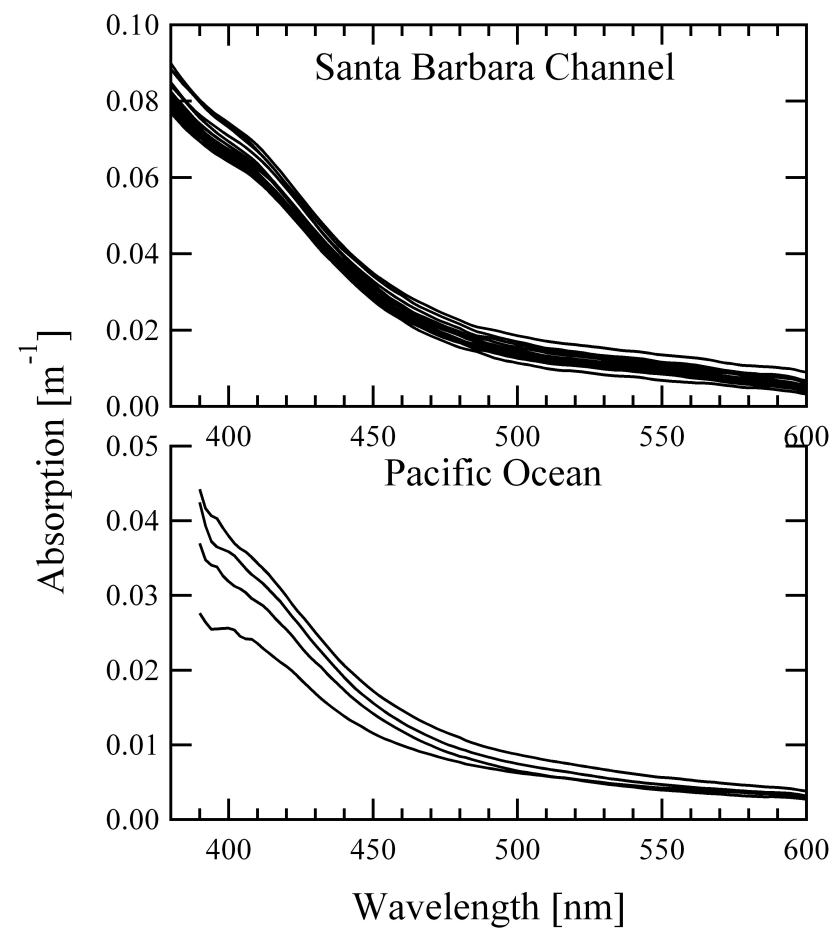

Fig. 5. Light absorption of CDOM from subsurface depths $(80-200 \mathrm{~m})$ of samples from (a) the Santa Barbara Channel (California, Northeast Pacific) and (b) from offshore of New Caledonia (West Pacific).

at $415 \mathrm{~nm}$ most likely corresponds to the CDOM absorption shoulder found at the same wavelength in the extract.

To examine the geographic distribution of the 415-nm fluorophore, excitation spectra of each sample were recorded with the same fluorometer settings and amplification, and thereafter normalized. With the exception of one sample from $>4000 \mathrm{~m}$, pronounced maxima at $415 \mathrm{~nm}$ were mainly found in the 200-m samples (Fig. 10). Surface samples showed smaller maxima, only pronounced in one sample. As there was a significant excitation at $415 \mathrm{~nm}$ even in samples from the surface, this background excitation from other chromophores in the DOM molecules was subtracted by using the excitation at $370 \mathrm{~nm}$ (outside of the $415-\mathrm{nm}$ maximum) and the mean ratio of Ex $370 \mathrm{~nm} / \mathrm{Ex} 415 \mathrm{~nm}$ from the surface samples. Thereby the 415-nm excitation of the fluorophore is calculated. The geographic distribution of this normalized 415-nm excitation from north to south is shown in Fig. 4 (lower panel). The CDOM absorption of the extract at $200 \mathrm{~m}$ showed high values in the highest latitudes (Gulf of Biscay), low values in the subtropics $\left(40-23^{\circ} \mathrm{N}\right)$ and high values in the tropics with distinct maxima north and south of the equator. The absolute absorption was lower than those measured earlier during ANT-XXIII/1 on original water samples by a factor of four, probably due to a low DOM extraction efficiency. The 415-nm excitation maximum at 200-m depth was low at higher latitudes, steadily increasing 


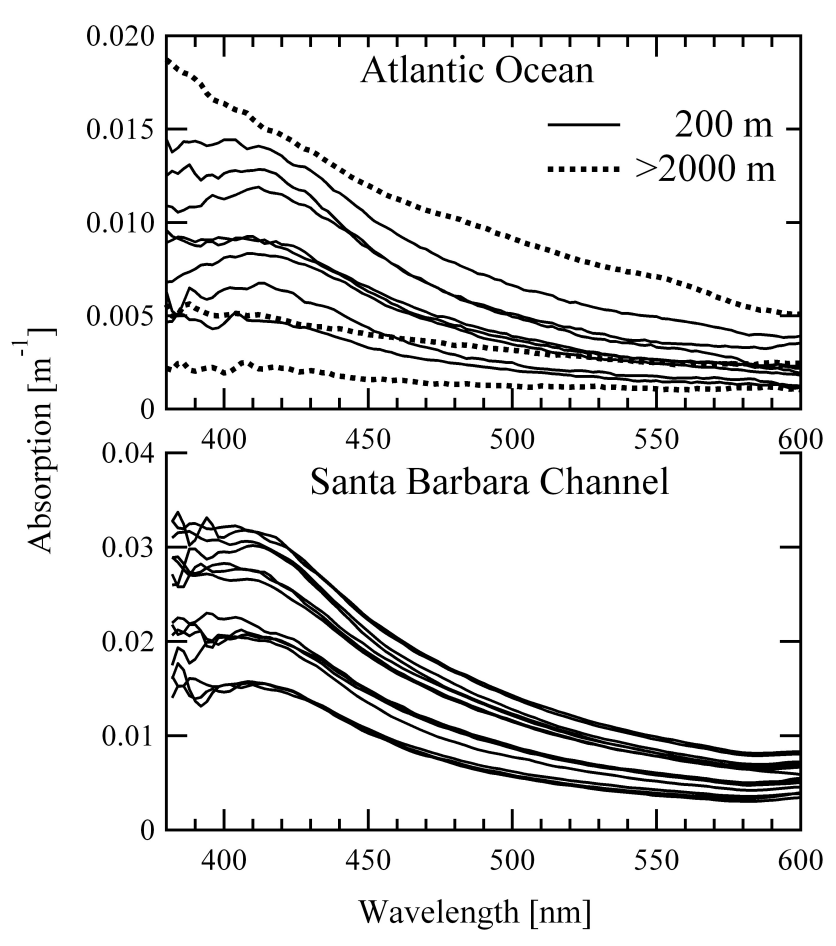

Fig. 6. Light absorption by particles of samples from subsurface depths taken in (a) the western Atlantic Ocean $(200 \mathrm{~m}$ and $>2000 \mathrm{~m}$ ), and (b) the Santa Barbara Channel (California, Northeast Pacific, 80-200 m).

throughout the subtropics and highest in the tropics (Fig. 4, lower panel).

\section{Discussion}

\subsection{CDOM and particulate absorption of subsurface waters}

The CDOM absorption spectra from the subsurface water samples in the eastern Atlantic Ocean showed a clear absorption shoulder at ca. $415 \mathrm{~nm}$ that is similar to the shoulder found in the Arabian Sea in $600 \mathrm{~m}$ (Breves and Reuter, 2000; Breves, 2001; Breves et al., 2003). The shoulder was absent in samples from the sea surface, most pronounced at depths below the surface mixing layer, i.e. in and below the DCM, and extended into the OMZ. The underlying 415-nm chromophore absorption was partly correlated with the extent of the oxygen minimum, as can be seen from the AOU profiles in the tropical Atlantic (Fig. 3). This chromophore was also found in subsurface coastal waters of the Santa Barbara Channel and in offshore waters near New Caledonia, both in the Pacific Ocean. Considering that it was earlier found in the Indian Ocean, it is likely that it is a typical feature of the subsurface CDOM in all major oceans, although our samples were taken mainly in the subtropics and tropics. For verification we checked the absorption characteristics of a data set from the same area derived from the "ICESS Global CDOM Project"

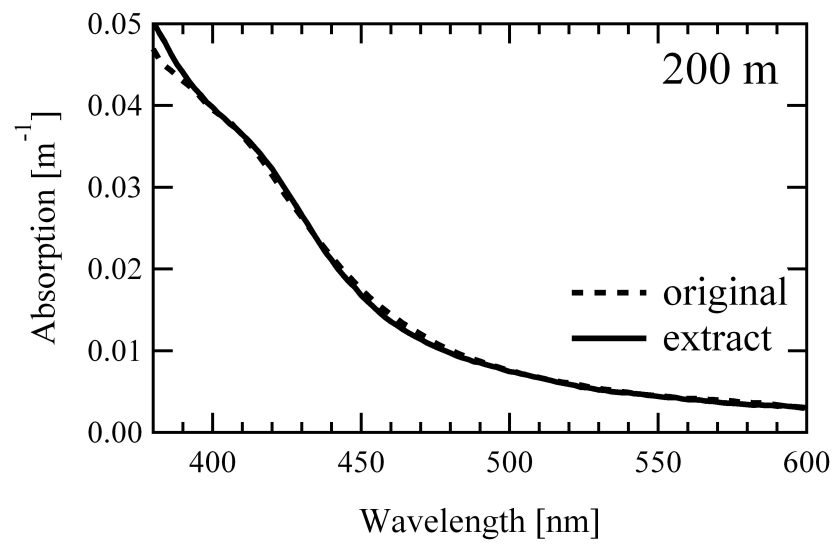

Fig. 7. CDOM absorption spectra of a methanolic DOM extract from $200 \mathrm{~m}$ and the absorption of the corresponding original sample. The absorption of the extract was adjusted to fit to the absorption of the original sample. Deviations at $<380 \mathrm{~nm}$ are due to larger measurement errors of the regular sample absorption at these wavelengths in the PSICAM measurements.

which showed the same absorption shoulder (personal communication).

The particulate absorption spectra from the subsurface water samples in the Atlantic Ocean and SBC also showed an absorption maximum at $415 \mathrm{~nm}$ (Fig. 6). The absorption of the chromophore in the particulate fraction of the 200-m samples from the Atlantic Ocean was lower than in the CDOM fraction. If the same chromophore occurs in both fractions, it is likely that particles are the source for the dissolved chromophore. It should be noted that in most cases the particulate absorption of deeper water was below the detection limit. The particulate fraction in deeper water consists mainly of detrital matter and bacteria. Surface detritus showed a similar exponentially decreasing absorption as CDOM; this can be assumed for open ocean deep waters as well. Absorption by non-colored marine bacteria (or heterotrophic flagellates, ciliates) usually shows a strong maximum of the respiratory enzyme (i.e. cytochrome $c$ ) which absorbs strongest around 410 to $415 \mathrm{~nm}$ (Yentsch, 1962; Morel and Ahn, 1990, 1991; Stramski and Kiefer, 1990); a similar absorption maximum is found here in the particulate fraction.

\subsection{CDOM extracts}

The CDOM absorption shoulder of the seawater samples was also found in the methanolic DOM extracts (Fig. 7). The fluorescence analysis of these extracts was initiated by the observation of a specific fluorescence at $660 \mathrm{~nm}$ (Ex: $420 \mathrm{~nm}$ ) in the OMZ of the Arabian Sea (Breves, 2000; Breves et al., 2003). The authors speculated that this fluorescence was related to a 415-nm CDOM absorption shoulder observed in the same depths. However, there was still no evidence that these two observations originate 


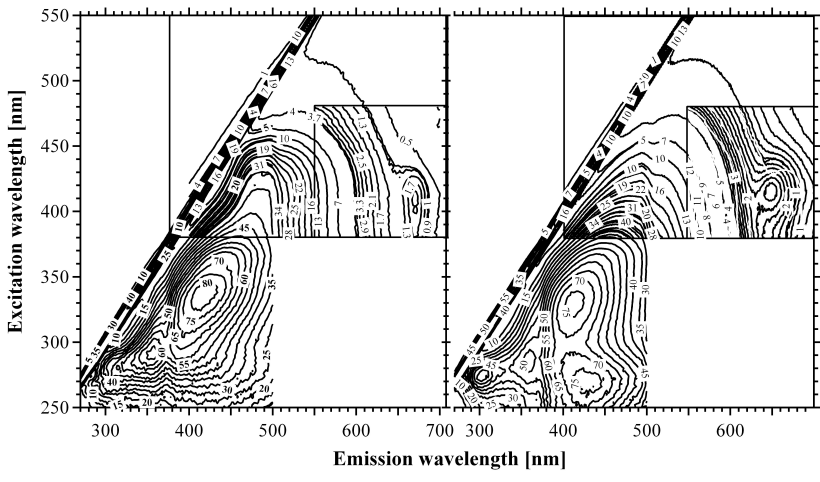

Fig. 8. Fluorescence excitation-emission matrices of a sample taken at the surface (left panel) and at 200-m depth (right panel) in the east Atlantic Ocean during ANT-XXV/1. Each graph shows a composite of three matrices recorded from the same sample with different detector amplification to adjust for the low fluorescence emission at longer wavelengths. Note that fluorescence is given in arbitrary units and amplification differences between measurements are not adjusted to see the otherwise faint Ex/Em maxima at longer wavelength in more detail.

from the same molecule or compound. The fluorescence EEM analysis showed Ex/Em maxima, particularly around 330/420 nm, which are typical for oceanic DOM (e.g. Coble, 1996; Coble et al., 1998). In addition, there are distinct maxima with emission at longer wavelengths, which are usually not measured in most DOM-EEM studies due to the very low fluorescence signal (exception: Coble et al., 1998). Samples derived from the surface and from $200 \mathrm{~m}$ showed a peak at $410 / 670 \mathrm{~nm}(\mathrm{Ex} / \mathrm{Em})$ and at $415 / 650 \mathrm{~nm}$, respectively (Fig. 8). For the surface sample the peak fits well to the fluorescence of chlorophyll $a$ or its degradation products (Peak P, $410 \mathrm{~nm} / 680 \mathrm{~nm}$ in Coble et al., 1998). The small wavelength shift in the emission and excitation maximum compared to that found by Coble et al. (1998) could be explained by the different solvent (methanol vs. water). The peak at $415 \mathrm{~nm} / 650 \mathrm{~nm}$ was not described earlier, neither for surface nor for subsurface DOM samples. Only a 660-nm emission (for 420-nm excitation) was observed in situ (Breves, 2000; Breves et al., 2003). It is most likely that this $660-\mathrm{nm}$ emission peak is derived from the same common fluorophore.

The excitation spectrum can be used to get information on the related spectral absorption for each emission maximum. The fluorescence at $650 \mathrm{~nm}$ is linked to an absorption maximum at $415 \mathrm{~nm}$, whereas the emission at $670 \mathrm{~nm}$ relates to absorption at $410 \mathrm{~nm}$ (Fig. 8). The absorption characteristics of each fluorophore were further analyzed by more precise excitation spectra (Fig. 9). The underlying chromophore for the 670-nm fluorescence at the sea surface showed the characteristic absorption of a chlorophyll $a$ degradation product, e.g. pheophytin $a$, pheophorbide $a$, protopheophorbide $a$ (which all have the same absorption characteristics, e.g. Jeffrey et al., 2007). The absorption characteristic of the chromophore in the subsurface water was clearly different from these chlorophyll $a$ derivatives. First, there was no strong absorption maximum in the red region $(650-670 \mathrm{~nm})$, and second, the strong Soret maximum was shifted to $415 \mathrm{~nm}$ with the minor maxima being broader and at longer wavelengths (Fig. 9). In conclusion, the specific chromophore/fluorophore of the subsurface samples was not directly related to that found in surface waters. Its absorption and fluorescence characteristics fit more to a non-chlorin porphyrin molecule. We tried to identify target structures and molecular formulas in the data sets for this issue (Flerus et al., 2012; Hertkorn et al., 2012). Although Hertkorn et al. identified nitrogen heterocycles which might be related to a porphyrin, its molecular identification is still subject to ongoing research.

\subsection{Geographic distribution}

In addition to the determination of the chromophore absorption at $415 \mathrm{~nm}, a_{\mathrm{c}} 415 \mathrm{~nm}$, the $650-\mathrm{nm}$ fluorescence can be used to roughly quantify the $415-\mathrm{nm}$ chromophore. Therefore excitation spectra (Em: $650 \mathrm{~nm}$ ) were recorded for each extract. The normalized excitation at $415 \mathrm{~nm}$ and the $a_{\mathrm{c}} 415 \mathrm{~nm}$ values were used as an indication for the 415-nm chromophore concentration over the latitudinal transect in the Atlantic Ocean between $50^{\circ} \mathrm{N}$ and $25^{\circ} \mathrm{S}$ during the same season (October/November) of two different years. The chromophore concentration was high in the tropics when the CDOM absorption was high as well. There was a significant correlation between the chromophore concentration and the general CDOM concentration in the tropical Atlantic Ocean $\left(a_{\mathrm{c}} 415 \mathrm{~nm}\right.$ vs. $a_{415 \mathrm{~nm}}, r^{2}=0.87$, $n=20, p<0.001)$, where $a_{\mathrm{c}} 415 \mathrm{~nm}$ represented between 20 and $30 \%$ of the $a_{415} \mathrm{~nm}$ in the subsurface water. The lower values at $200 \mathrm{~m}$ in the south are partly due to the fact that the $\mathrm{OMZ}$ is at higher depths than north of $15^{\circ} \mathrm{S}$, and hence, are related to differences in the water masses. However, the low sample resolution prevents resolving how the $415-\mathrm{nm}$ chromophore is related to the specific water masses. There is strong evidence that the 415-nm absorption shoulder is directly related to the fluorescence at $650 \mathrm{~nm}$. This fluorescence most probably can be detected by regular chlorophyll $a$ fluorometers. For example, a relatively high chlorophyll-like fluorescence was found in the deeper water (Fig. 3), even higher in the OMZ, similar to the fluorescence profile observed by Breves et al. (2003), but there was no chlorophyll-like fluorescence detectable in the samples from the subsurface water. However, the fluorescence emission at $650 \mathrm{~nm}$ was likely detected earlier as "deep red fluorescence" (Broenkow et al., 1983, 1985, 1992; Lewitus and Broenkow, 1985 (their "third" fluorescence maximum); and by Breves and co-workers (Breves and Reuter, 2000; Breves, 2001; Breves et al., 2003)). Breves and co-workers reported this fluorescence from the Arabian Sea in the tropical Indian 


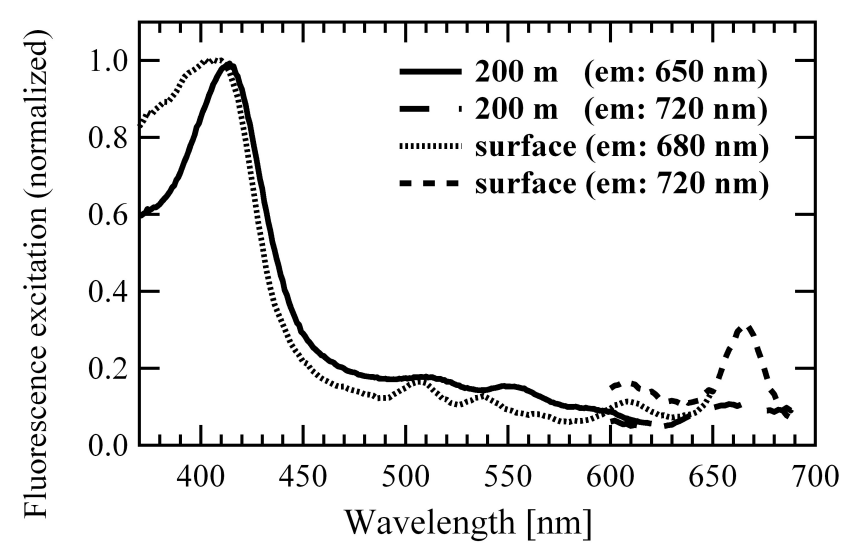

Fig. 9. Single fluorescence excitation spectra from the same two samples as in Fig. 8. The specific emission wavelengths used for the measurements are shown in the legend.

Ocean, and Broenkow and co-workers from the eastern Pacific Ocean ranging from tropical to temperate regions. Broenkow and co-workers were one of the first to measure red fluorescence in deeper waters. Previously, Lewitus and Broenkow (1985) speculated from their observations that the maximum of the deep red fluorescence is associated with the OMZ and that it might be a geographically widespread feature. Combining the observation of the deep red fluorescence with that of the 415-nm absorption shoulder, this specific chromophore/fluorophore can be found in tropical regions of all major oceans, as well as in subtropical and temperate regions of the Pacific Ocean. Concentrations in the temperate to subtropical Atlantic Ocean were relatively low, but still detectable. The "third" fluorescence maximum (Broenkow et al., 1983) was found in depths of the OMZ, and the extent of the 415-nm absorption shoulder was high in the OMZ correlating with the AOU. However, the absorption shoulder was also high in depths of the DCM below the vertical mixing zone in the tropical Atlantic. Any red fluorescence by this fluorophore might be covered by chlorophyll fluorescence from phytoplankton in the DCM. Broenkow and co-workers, however, observed a clear fluorescence minimum between the surface maximum and the "third" maximum, which could not be observed yet for the absorption shoulder, probably due to the low vertical resolution. More information is needed to resolve the relationship between OMZ and this fluorophore, but from the absorption results it is clear that it does not exclusively occur in the OMZ, as the absorption shoulder was also found in about $100-200 \mathrm{~m}$ of the Santa Barbara Channel, a coastal environment.

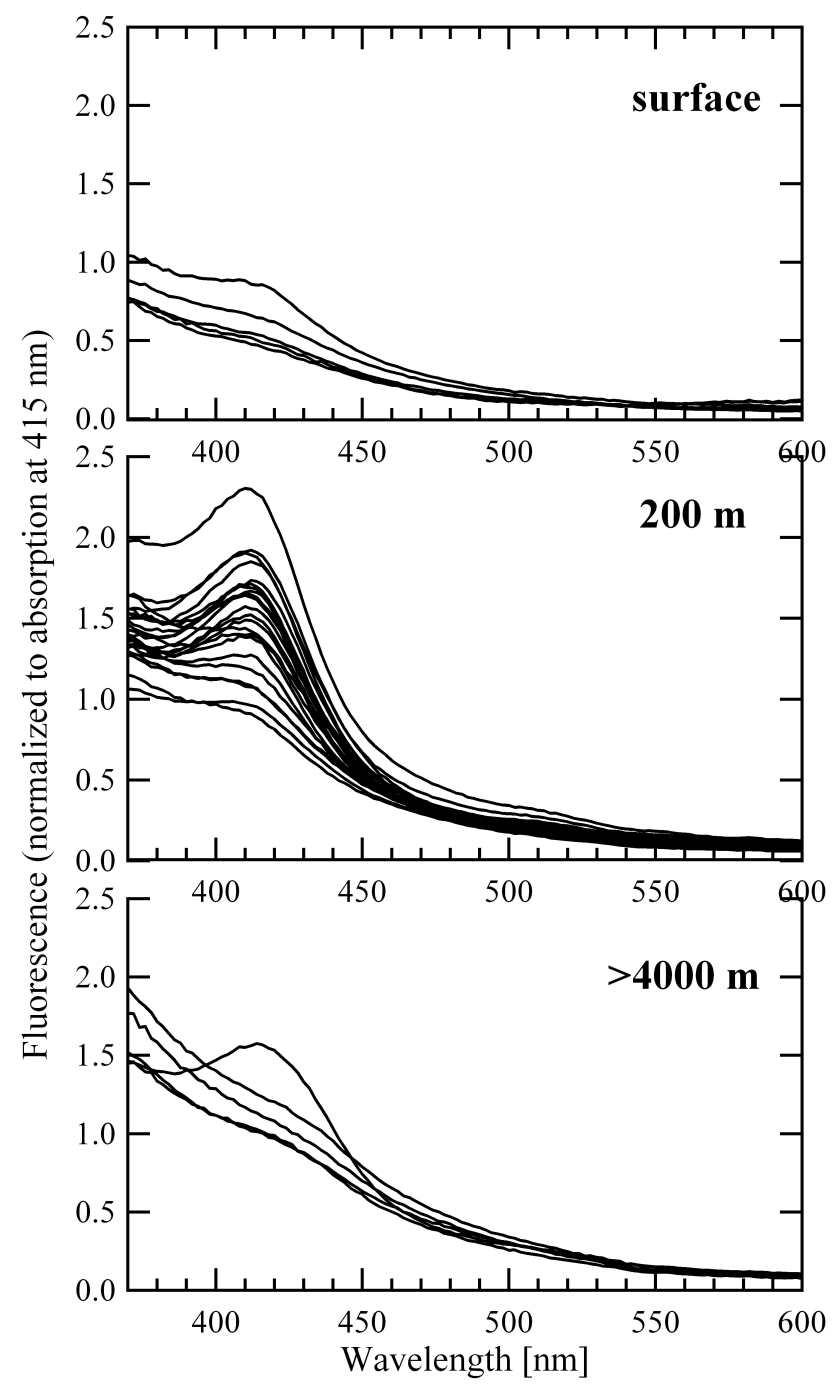

Fig. 10. Excitation spectra for the 650-nm emission maxima for samples taken in the eastern Atlantic Ocean during ANT-XXV/1 at (a) the surface, (b) $200 \mathrm{~m}$ depth, (c) depths of $>4000 \mathrm{~m}$.

\subsection{Possible origin of the chromophore/fluorophore}

Our data show that an absorption shoulder at around $415 \mathrm{~nm}$ is observed in the dissolved and in the particulate fraction in samples from subsurface depth in the ocean. We assume that the chromophore in the particulate fraction is the same as in the dissolved fraction, although with a clearly lower concentration. It can therefore be stated that this 415-nm chromophore was generally found in the "dissolved" phase. It probably originates from the particulate fraction either from bacteria or detrital particles sinking down from the euphotic zone. Earlier observations were contradicting: Broenkow et al. (1992) concluded from an often significant correlation with attenuation (mainly scattering by particles) that the deep fluorescence originates from the particulate fraction, whereas Breves et al. (2003) 
found it mainly in the dissolved fraction. The particulate absorption at ca. $415 \mathrm{~nm}$ found in subsurface waters is similar to earlier observations of bio-detritus (e.g. Kishino et al., 1985; Bricaud and Stramski, 1990) and can be explained by absorption of heterotrophs, like bacteria, ciliates, and flagellates (e.g. Stramski and Kiefer, 1990; Morel and Ahn, 1990, 1991; Stramski and Kiefer, 1998).

As the absorption takes place in the visible spectral region, this chromophore by definition is part of a pigment; hence, this observation shows the occurrence of high concentrations of a pigment degradation product in the dissolved phase that is accumulated in subsurface waters by either a high production or a low remineralization rate. The optical characteristics of the chromophore/fluorophore do not support that the molecule is an early chlorophyll $a$ degradation product, but match in absorption and fluorescence to that of a non-chlorin, metal-free porphyrin, like degradation products of hemes, cytochromes, and chlorophyll $c$, etc. The particulate absorption of heterotrophic bacterial cultures showed maxima at $409 \mathrm{~nm}$ (Stramksi and Kiefer, 1998) or 412-415 nm (Morel and Ahn, 1990) and weak absorption maxima at 525 and $555 \mathrm{~nm}$ (Morel and Ahn, 1991). Methanolic extract of the heterotrophic pigments showed an absorption maximum around $415 \mathrm{~nm}$. This absorption features corresponds to the maxima found in the DOM fluorescence excitation spectra from subsurface samples, making bacteria one possible source for this chromophore. In tropical regions, where Prochlorococcus sp. and Synecchococcus sp. often dominate the phytoplankton communities (Taylor et al., 2011), the high chromophore concentrations suggest both organism classes to be a potential source. Some Prochlorococcus sp. communities were also found in depth of $120-140 \mathrm{~m}$ with very low oxygen in areas where the OMZ is very pronounced, like the Arabian Sea and the eastern tropical North Pacific (Goericke et al., 2009), and produced a clear secondary fluorescence maximum in these depths.

The specific fluorescence at $650 \mathrm{~nm}$ and absorption at $415 \mathrm{~nm}$ may be a unique feature of a pigment molecule or a group of similar molecules in DOM of subsurface waters. If its biogeochemistry (remineralization, degradation, production rates, etc.) is known, the simple optical detection of this chromophore could make it suitable as a tracer for e.g. bacterial production, or POM and DOM remineralization.
Acknowledgements. We thank captains and crews of $\mathrm{R} / \mathrm{V}$ Polarstern, R/V L'Alis, and R/V Kilo Moana for their help and support. The DOM extracts were kindly taken by Walter Geibert, Oliver Lechtenfeld, and Ruth Flerus. Gereon Budeus kindly provided the CTD and oxygen data from ANT-XXIII/1. The participation of R. Röttgers on the R/V L'Alis cruise was supported by the "VALHYBIO/PNTS" project.

Edited by: G. Kattner

\section{References}

Bauer, J. E., Williams, P. M., and Druffel, E. R. M.: 14C activity of dissolved organic carbon fractions in the north-central Pacific and Sargasso Sea, Nature, 357, 667-670, 1992.

Benner R.: Chemical composition and reactivity of dissolved organic matter, in: Biogeochemistry of marine dissolved organic matter, edited by: Hansell, D. A. and Carlson, C. A., Academic Press, 59-90, 2002.

Breves, W.: Bio-Optik im Arabischen Meer: Datenanalyse und Modellierung, Dissertation, Uni Oldenburg - VII, 172 Bl., Oldenburg, 2001.

Breves, W. and Reuter, R.: Bio-optical properties of gelbstoff in the Arabian Sea at the onset of the southwest monsoon, Proc. Ind. Acad. Sci. EPS, 109, 415-425, 2000.

Breves, W., Heuermann, R., and Reuter, R.: Enhanced red fluorescence emission in the oxygen minimum zone of the Arabian Sea, Ocean Dynam., 53, 86-97, doi:10.1007/s10236-003-0026-y, 2003.

Bricaud, A. and Stramski, D.: Spectral absorption coefficients of living phytoplankton and nonalgal biogenous matter: A comparison between the Peru upwelling area and the Sargasso Sea, Limnol. Oceanogr., 35, 562-582, 1990

Broenkow, W. W., Lewitus, A. J., Yarbrough, M. A., and Krenz, R. T.: Particle fluorescence and bioluminescence distributions in the eastern tropical Pacific, Nature 302, 329-331, 1983.

Broenkow, W. W., Lewitus, A. J., and Yarbrough, M. A.: Spectral observations of pigment fluorescence in intermediate depth waters of the North Pacific, J. Mar. Res., 43, 875-891, 1985.

Broenkow, W. W., Yuen, M. A., and Yarbrough, M. A.: VERTEX: biological implications of total attenuation and chlorophyll and phycoerythrin fluorescence distributions along a 2000-m deep section in the Gulf of Alaska, Deep-Sea Res. 39, 417-437, 1992.

Cavazza, C., Guidici-Orticoni, M.-T., Nitschke, W., Appia, C., Bonnefoy, V., and Bruschi, M.: Characterisation of a soluble cytochrome c4 isolated from Thiobacillus ferrooxidans, Eur. J. Biochem. 242, 308-314, 1996.

Coble, P. G..: Characterization of marine and terrestrial DOM in seawater using excitation-emission matrix spectroscopy, Mar. Chem. 51, 325-346, 1996.

Coble, P. G..: Marine optical biogeochemistry: the chemistry of ocean color, Chem. Rev., 107, 402-418, doi:10.1021/cr050350, 2007.

Coble, P. G., Green S. A., Blough, N. V., and Gagosian, R. B.: Characterization of dissolved organic matter in the Black Sea by fluorescence spectroscopy, Nature, 348, 432-435, 1990. 
Coble, P. G., Carlos E., Del Castillo, C. E., and Avril, B.: Distribution and optical properties of CDOM in the Arabian Sea during the 1995 Southwest Monsoon, Deep-Sea Res. Pt. II, 45, 2195-2223, doi:10.1016/S0967-0645(98)00068-x, 1998.

Del Castillo, C. E. and Coble, P. G.., Seasonal variability of the colored dissolved organic matter during the 1994-95 NE and SW Monssons in the Arabian Sea. Deep Sea Res. Pt. II, 47, 15631579, 2000.

Dittmar, T., Koch, B., Hertkorn, N., and Kattner, G..: A simple and efficient method for the solid-phase extraction of dissolved organic matter (SPE-DOM) from seawater, Limnol. Oceanogr. Methods, 6, 230-235, 2008.

Flerus, R., Lechtenfeld, O. J., Koch, B. P., McCallister, S. L., Schmitt-Kopplin, P., Benner, R., Kaiser, K., and Kattner, G.: A molecular perspective on the ageing of marine dissolved organic matter, Biogeosciences, 9, 1935-1955, doi:10.5194/bg-9-19352012, 2012.

Goericke, R., Olson, R. J., and Shalapyonok, A.: A novel niche for Prochloococcus sp. in low-light suboxic environments in the Arabian Sea and the Eastern Tropical North Pacific, Deep-Sea Res., 47, 1183-1205, 2000.

Helms, J. R., Stubbins, A., Ritchie, J. D., Minor, E. C., Kieber, D. J., and Mopper, K.: Absorption spectral slopes and slope ratios as indicators of molecular weight, source, and photobleaching of chromophoric dissolved organic matter, Limnol. Oceangr., 53, 955-969, 2008.

Hertkorn, N., Harir, M., Koch, B. P., Michalke, B., Grill, P., and Schmitt-Kopplin, P.: High field NMR spectroscopy and FTICR mass spectrometry: powerful discovery tools for the molecular level characterization of marine dissolved organic matter from the South Atlantic Ocean, Biogeosciences Discuss., 9, 745-833, doi:10.5194/bgd-9-745-2012, 2012.

Jeffrey, S. W., Mantoura, R. F. C., and Wright, S. W.: Phytoplankton Pigments in Oceanography: Guidelines to ModernMethods, UNESCO, Paris, 1997, p. 207, Chapter 7, 2007.

Koch, B. P. and Kattner, G.: Preface "Sources and rapid biogeochemical transformation of dissolved organic matter in the Atlantic surface ocean", Biogeosciences, 9, 2597-2602, doi:10.5194/bg-9-2597-2012, 2012.

Koch, B. P., Witt, M., Engbrodt, R., Dittmar, T., and Kattner, G.: Molecular formulae of marine and terrigenous dissolved organic matter detected by electrospray ionisation Fourier transform ion cyclotron resonance mass spectrometry, Geochim. Cosmochim. Ac., 69, 3299-3308, 2005.

Kishino, M., Takahashi, M., Okami, N., and Ichimura, S.: Estimation of the spectral absorption coefficients of phytoplankton in the sea, Bull. Mar. Sci., 37, 634-642, 1985.

Lakowicz, J. R.: Principles of Fluorescence Spectroscopy, Springer, New York, 1999.

Lewitus, A. J. and Broenkow, W. W.: Intermediate depth pigment maxima in oxygen minimum zones, Deep-Sea Res., 32, 1101$1115,1985$.

McCarthy, M., Hedges, J. I., and Benner, R.: Major bacterial contribution to marine dissolved organic nitrogen, Science, 281, 231-234, 1998.

Miller, R. L., Belz, M., Del Castillo, C., and Trzaska, R.: Determining CDOM absorption spectra in diverse coastal environments using a multiple pathlength, liquid core waveguide system, Cont. Shelf Res. 22, 1301-1310, 2002.
Morel, A. and Ahn Y.-H.: Optical efficiency factors of free-living marine bacteria: Influence of bacterioplankton upon the optical properties and particulate organic carbon in oceanic waters, J. Mar. Res., 48, 145-175, 1990.

Morel, A. and Ahn Y.-H.: Optics of heterotrophic nanoflagellates and ciliates: a tentative assessment of their scattering role in oceanic waters compared to those of bacteria and algal cells, J. Mar. Res., 49, 177-202, 1991.

Nelson, L., Thomas, D. N., Stedmon, C., Granskog, M. A., Papadimitriou, S., Krapp, R. H., Meiners, K. M., Lannuzel, D., van der Merwe, P., and Dieckmann, G., The characteristics of dissolved organic matter (DOM) and chromophoric dissolved organic matter (CDOM) in Antarctic sea ice, Deep Sea Res. Pt. II, 58, 1075-1091, 2011.

Nelson, N. B., Siegel, D. A., and Michaels, A.F., Seasonal dynamics of colored dissolved material in the Sargasso Sea, Deep Sea Res. Pt. I, 45, 931-957, 1998.

Nelson, N. B., Siegel, D. A., Carlson, C. A., Swan, C. M., Smethie Jr., W. M., Khatiwala, S., Hydrography of chromophoric organic matter in the North Atlantic, Deep Sea Res. Pt. I, 54, 710-731, 2007.

Nelson, N. B., Siegel, D. A., Carlson, C. A., Swan, C. M., Tracing global biogeochemical cycle and meridional overturning circulation using chromophoric dissolved organic matter, Geophys. Res. Lett., 37, L03610, doi:10.1029/2009GL042325, 2010.

Röttgers, R. and Doerffer, R.: Measurements of optical absorption by chromophoric dissolved organic matter using a point-source integrating-cavity absorption meter, Limnol. Oceanogr. Meth., 5, 126-135, 2007.

Röttgers, R., Häse, C., and Doerffer, R.: Determination of the particulate absorption of microalgae using a point-source integrating-cavity absorption meter: verification with a photometric technique, improvements for pigment bleaching, and correction for chlorophyll fluorescence, Limnol. Oceanogr. Meth., 5, 1-12, 2007.

Stedmon, C. A., Markager, S., and Bro, R.: Tracing dissolved organic matter in aquatic environments using a new approach to fluorescence spectroscopy, Mar. Chem., 82, 239-254, doi:10.1016/S0304-4203(03)00072-0, 2003.

Steinberg, D. K., Nelson, N. B., Carlson, C. A., and Prusak, A. C.: Production of chromophoric dissolved organic matter (CDOM) in the open ocen by zooplankton and the colonial cynaobacterium Trichodesmium spp., Mar. Ecol. Prog. Ser. 267, 45-56, 2004.

Stramski, D. and Kiefer, D. A.: Optical properties of marine bacteria, Proc. SPIE 1302, 250, doi:10.1117/12.21450, 1990.

Stramski, D. and Kiefer, D. A.: Can heterotrophic bacteria be important to marine light absorption? J. Plankton Res., 20, 1489-1500, doi:10.1093/plankt/20.8.1489, 1998.

Swan, C. M., Siegel, D. A., Nelson, N. B., Carlson, C. A., and Nasir, E., Biogeochemical and hydrographic controls on chromophoric dissolved organic matter distribution in the Pacific Ocean, Deep Sea Res. Pt. I, 56, 2175-2192, 2009.

Taylor, B. B., Torrecilla, E., Bernhardt, A., Taylor, M. H., Peeken, I., Röttgers, R., Piera, J., and Bracher, A.: Bio-optical provinces in the eastern Atlantic Ocean and their biogeographical relevance, Biogeosciences, 8, 3609-3629, doi:10.5194/bg-8-3609-2011, 2011. 
Vodacek, A., Blough, N. V., DeGranpre, M. D., Peltzer, E. T., and Nelson, R. K.: Seasonal variation of CDOM and DOC in the Middle Atlantic Bight: terrestrial inputs and photooxidation, Limnol. Oceanogr., 42, 674-686, 1997.
Yentsch, C. S.: Measurement of visible light absorption by particulate matter in the ocean, Limnol. Oceanogr, 1, 207-217, 1962.

Williams, P. M. and Druffel, E. R. M.: Radiocarbon in dissolved organic matter in the central North Pacific Ocean, Nature 330, 246-248, 1987. 